\title{
A História da Arquitetura Brasileira e a Preservação do Patrimônio Cultural ${ }^{1}$
}

Maria Lucia Bressan Pinheiro*

\section{Resumo}

O presente trabalho procura enfocar o surgimento de uma consciência preservacionista no Brasil a partir de um ponto de vista pouco explorado: o mapeamento dos primeiros e incipientes estudos sobre a arquitetura brasileira, considerados aqui um dos primeiros indícios da emergência de preocupações relativas à preservação do patrimônio cultural. Destaca-se, deste ponto de vista, a obra de Debret, que permanece uma referência para as primeiras iniciativas relacionadas ao desenvolvimento de uma história da arquitetura brasileira de cunho operacional, ligada à corrente Neocolonial. Tais iniciativas partem de dois centros irradiadores: o grupo paulista, baseado nas idéias de Ricardo Severo; e o grupo carioca, centrado em José Mariano Filho. Além de corroborar o eurocentrismo característico da cultura brasileira, a abordagem ensaiada indica a necessidade de aprofundamento em outros aspectos, como a proximidade de algumas das mais importantes figuras do modernismo com o movimento neocolonial; a curta passagem de José Mariano Filho pela Diretoria da Escola Nacional de Belas Artes (ENBA) do Rio de Janeiro; e o papel instigador do poeta modernista Manuel Bandeira nos últimos anos da década de 1920.

Palavras-chave: Preservação do patrimônio cultural. História da arquitetura brasileira. Neocolonial.

\section{The Brazilian Architecture History and the Preservation of Cultural Heritage}

The following paper approaches the emergence of a preservationist conscience in Brazil from a non-exploited point of view: the identification of the first, incipient studies about Brazilian colonial architecture, considered here as one of the earliest signs of concern about the preservation of our cultural heritage. From such an approach, the work of the French painter Jean Baptiste Debret - settled in Brazil as part of the 'French Artistic Mission' of 1816 - stands out as a reference for the first initiatives aiming at the development of a history of Brazilian architecture of an operational kind, 
related to the Neocolonial tendency of the 1920's. Two main radiating centers can be identified: one in São Paulo, based on the ideas of the Portuguese engineer Ricardo Severo; and one in Rio de Janeiro, grouped around José Mariano Filho. Besides corraborating the Eurocentrism typical of the Brazilian culture at the time, the study has pointed out other aspects that deserve further research, such as: the involvement of some of the most important members of the modernist group with Neocolonial initiatives; the short mandate of José Mariano Filho as Director of the National School of Fine Arts in Rio de Janeiro; and the instigating role played by the modernist poet Manuel Bandeira in the last years of the decade of 1920.

Key-words: Preservation of cultural heritage. Brazilian architecture history. Neocolonial architecture.

"Para bem restaurar, é necessário amar e entender o monumento, seja estátua, quadro ou edifício, sobre o qual se trabalha... Ora, que séculos souberam amar e entender as belezas do passado? E nós, hoje, em que medida sabemos amá-las e entendê-las?"

Camillo Boito, 1884 .

Em entrevista ao jornal carioca Diário da Noite, em 19 de maio de 1936, sobre os trabalhos iniciais do recém-criado SPHAN, Rodrigo Melo Franco de Andrade referiu-se à "... velhíssima igreja do Rosário, de estilo românico e em cujo pórtico se destacam ornatos devidos ao Aleijadinho" (ANDRADE, 1987, p.24, grifos nossos) - deixando transparecer, assim, a insipiência dos conhecimentos então disponíveis sobre a arquitetura brasileira.

Essa afirmação é tanto mais surpreendente se pensarmos que seu autor fazia parte dos mais elevados círculos intelectuais do país, sendo, também, particularmente sensível a questões relativas à arte e cultura brasileiras.

O episódio evidencia um aspecto até agora pouco abordado no âmbito do debate atual sobre a preservação do patrimônio brasileiro: o grau de relativo desconhecimento a esse respeito em que até hoje nos encontramos. Embora avanços venham sendo alcançados, persistem muitas lacunas no estudo e documentação da arquitetura brasileira. 
Analisando a questão de uma perspectiva mais ampla, é possível localizar as origens de tal situação - que, diante das palavras de Camillo Boito, na epígrafe acima -, configura-se, a nosso ver, como indício seguro do desapego para com o patrimônio cultural brasileiro ainda vigente hoje.

De fato, nascido por assim dizer sob o signo da tão invocada globalização, em seu momento inicial, que podemos situar na grande expansão ultramarina portuguesa, o Brasil acabou de completar cinco séculos desde seu descobrimento. Entretanto, foi necessário o decurso de mais de duzentos anos até a emergência das primeiras atitudes de afirmação de uma identidade nacional, que costuma ser identificada com os movimentos em busca da autonomia política, dos quais o mais importante é a Inconfidência Mineira, em 1789, sediada em Ouro Preto.

Por sua vez, o século XIX caracterizou-se, entre nós, pela franca abertura à cultura européia em geral, e francesa em particular - inclusive com patrocínio oficial, como aconteceu no episódio da Missão Francesa. A paulatina inserção de algumas regiões brasileiras no mercado internacional, através da produção de determinadas matérias-primas - o café, o algodão, a borracha -, facilitando intercâmbios de todos os tipos, veio reforçar o processo. No final do século, há uma associação clara, por parte das elites brasileiras, entre valores culturais europeus e as noções vigentes de modernidade e de civilização, manifestados nos costumes, nas artes, na moda, com destaque para a arquitetura, capaz de evocar / emular paisagens urbanas dignas das metrópoles européias. Pretendia-se esquecer, obliterar mesmo, o passado colonial, primitivo, retrógrado, tacanho, em nome do progresso.

Esta é, de fato, a atitude predominante no período; e dela são emblemáticas as reformas urbanas realizadas no Rio de Janeiro pelo prefeito Pereira Passos, já nos primeiros anos do século XX. Destaca-se, aí, o episódio da abertura da avenida Central, entre 1904 e 1906, que implicou no arrasamento de extensa área do antigo núcleo colonial da cidade, substituído pelas mais modernas manifestações ecléticas européias. A avenida Central significou, de fato, a concretização da modernidade tão ansiada pela sociedade brasileira da época, como se percebe pela seguinte citação de Olavo Bilac a respeito do assunto:

No aluir das paredes, no ruir das pedras, ao esfarelar do barro, havia um longo gemido. Era o gemido soturno e lamentoso do Passado, do Atraso, do Opróbrio. A cidade colonial, imunda, retrógrada, emperrada nas suas velhas tradições, estava soluçando no soluçar daqueles apodrecidos materiais que 
desabavam. Mas o hino claro das picaretas abafava este protesto impotente. (In: RAMALHO, 1989, p.116).

O que Pereira Passos fez no Rio de Janeiro, aconteceu, guardadas as devidas proporções, em várias outras cidades brasileiras. São Paulo, em pleno surto de enriquecimento proporcionado pelo café, não poderia fugir à regra. Aí também floresceram iniciativas visando à modernização e ao embelezamento do velho burgo colonial, desde a atualização pontual das fachadas até reformas urbanas mais extensas. Assim, edifícios públicos foram reformados; largos e praças receberam paisagismo "à inglesa"; e igrejas foram demolidas - algumas devido ao alargamento da malha viária, outras para serem substituídas por templos modernos, mais condizentes com o novo status urbano da cidade, como a antiga Sé colonial, substituída pela catedral neogótica de Max Hehl.

Os exemplos continuam durante a década de 1920: no Rio de Janeiro, procede-se ao desmonte do morro do Castelo, tão saudado pela imprensa quanto a avenida Central; em Olinda, após a reforma goticizante realizada na Sé, cogitava-se de demolir a Igreja do Carmo, para abertura de um novo bairro; em Salvador, a Sé "talvez a igreja mais venerável da nossa terra pela antiguidade e pelo caráter", no dizer de Manoel Bandeira (In: PINHEIRO, 2005, p.36) - foi demolida para instalação do novo sistema de bondes, apesar da existência da Inspetoria Estadual de Monumentos Nacionais da Bahia, criada no ano anterior.

De um ponto de vista geral, portanto, tal contexto afigura-se totalmente impermeável à emergência de quaisquer laivos de interesse para com manifestações culturais autóctones - situação que só começa a mudar a partir da década de 1920, com o surgimento do primeiro movimento de valorização de nossas raízes - o Neocolonial, encabeçado em São Paulo por Ricardo Severo e, no Rio de Janeiro, por José Mariano Filho ${ }^{2}$ - e da proposição dos primeiros projetos de lei relativos ao assunto.

Nesse sentido, o presente trabalho propõe uma abordagem do tema a partir de um mapeamento dos primeiros e incipientes estudos a contemplar a produção arquitetônica nacional. Deste ponto de vista, parece caber indiscutivelmente ao insigne membro da Missão Francesa ${ }^{3}$, Jean Baptiste Debret, o título de patrono da história da arquitetura brasileira.

De fato, a despeito de sua posição como pintor histórico ${ }^{4}$ formado pela École des Beaux-Arts de Paris, Debret revelou-se surpreendentemente condescendente 
para com os hábitos e objetos cotidianos brasileiros, que retratou em inúmeras pranchas de sua obra Voyage pittoresque et historique au Brésil publicada na França entre 1834 e 1839. Se o pintor francês foi de fato seduzido pela pitoresca e exuberante sociedade tropical, ou se apenas anteviu no registro pictórico de tal tema uma fonte futura de recursos, não se sabe. $O$ fato é que, embora a principal contribuição de Debret para a história da arquitetura brasileira resida muito mais em suas vistas do Rio de Janeiro e nas pranchas de logradouros da cidade, suas escassas considerações especificamente voltadas a exemplares arquitetônicos autóctones - que se resumem a duas pranchas e respectivos comentários ${ }^{5}$ literalmente "fizeram história": de Ricardo Severo e José Mariano Filho ao círculo modernista carioca, todos tomaram como referência as sumárias análises do pintor francês.

Seria de supor que, depois dele, instituições como o Instituto Histórico e Geográfico Brasileiro (IHGB), e seus sucedâneos estaduais, tivessem canalizado parte de seu zelo positivista para o estudo de monumentos históricos brasileiros, se não mesmo para a sua preservação. Este não parece ter sido o caso, entretanto, a julgar pelas atitudes de alguns de seus mais destacados membros diante do patrimônio histórico nacional, como a sumária dinamitação - ordenada por Teodoro Sampaio em 1896 - do arcabouço mural da igreja dos jesuítas do Pátio do Colégio, em São Paulo, que se mantivera solidamente em pé após o desabamento de sua cobertura.

Igualmente significativa é a reforma descaracterizadora realizada por volta de 1907 no antigo Convento do Carmo do Rio de Janeiro, sede do IHGB, pelo seu então Primeiro Secretário, Max Fleiuss, que, em seu relatório de gestão, listou entre suas mais importantes realizações a "reforma das fachadas, substituindo o horrendo casarão por um edifício de agradável efeito arquitetônico" (In: KESSEL, 2002, p.47, grifo nosso).

Afigura-se excepcional, portanto, a "memória justificativa" da vistoria realizada por Euclides da Cunha nos Fortes de Bertioga, em $1904^{6}$, da qual transparece a preocupação com a preservação - em moldes inequivocamente ruskinianos - daqueles edifícios:

Trata-se de conservar duas grandes relíquias, que compensam a falta absoluta de qualquer importância, estreitamente utilitária, com o incalculável valor histórico que lhes advém das nossas mais remotas tradições.

Compreende-se, porém, que tais reparos tendam apenas a sustar a marcha das ruínas. Quaisquer melhoramentos ou retoques, que se executem, serão 
contraproducentes, desde que o principal encanto dos dois notáveis monumentos esteja, como de fato está, na sua mesma vetustez, no aspecto característico que lhe imprimiu o curso das idades. (CUNHA, 1966, p.67780).

Este assunto está a merecer pesquisas aprofundadas, pois é possível detectar mudanças de rumo na postura do IHGB a partir da década de 1920, em consonância com o debate cultural do período. De fato, em 1922 - talvez inspirado pela comemoração do Centenário da Independência -, o Instituto, na pessoa de seu presidente perpétuo, o Conde de Afonso Celso, intercedeu junto à Comissão Executiva da Exposição do Centenário "no sentido de salvar à ruína os edifícios históricos de Ouro Preto, vinculados ao episódio da Inconfidência Mineira", particularmente a Casa de Marília, a ser demolida para construção de um quartel. (PINHEIRO, 2005, p.11-2)

Mais tarde, em 1933, foi também ao IHGB que o Ministro da Educação Francisco Campos solicitou um inventário dos edifícios de valor histórico do Rio de Janeiro - que, ao que parece, acabou por não ser realizado (MARIANO FILHO, 1943, p.117).

Mas, de um ponto de vista mais benevolente para com a arquitetura tradicional brasileira, uma das únicas exceções a serem apontadas no contexto anterior a 1920 é a figura de Ernesto da Cunha de Araújo Viana, engenheiro de formação e professor da Escola de Belas Artes, cujas "sábias lições" foram mencionadas por Lúcio Costa em seu famoso artigo Depoimento de um arquiteto carioca (In: XAVIER, 1987, p.83). O incomum interesse de Araújo Viana pela arquitetura colonial manifestou-se, de fato, numa intensa atividade de articulista em periódicos da primeira década do século $X X$ na qual também ele recorria à autoridade de Debret em assuntos arquitetônicos. ${ }^{7}$

\section{Debret, o pioneiro}

Nesse sentido, é pertinente uma análise dos comentários de Debret a respeito da arquitetura brasileira, que - seja por sua autoridade como expoente de um grupo tão prestigiado quanto a Missão Francesa $^{8}$, seja pela escassez de outros estudos a respeito - tornaram-se referência para os primeiros que se debruçaram sobre o assunto depois dele, já no início do século XX. 
Embora logo de início dissesse não pretender, "... nem de longe, afirmar que a arquitetura brasileira tem um estilo original", Debret dispôs-se a "pesquisar-Ihe as fontes" - as quais, situadas na Península lbérica, sofreram a influência de todos os povos que por ali passaram: dos iberos e celtas originais aos mouros - cuja presença é muito destacada -, passando pelos romanos (1965, p.258-259). Aí já se evidenciam paralelismos com a famosa conferência "A Arte Tradicional no Brasil", proferida por Ricardo Severo quase cem anos depois, na qual o engenheiro português apresenta os tipos característicos da casa e do templo brasileiros, "que provém dos tipos de casas e templos peninsulares, vestidos com o estilo próprio do século XVI e seguintes, mas com o fundo tradicional que vem de influências anteriores, ibéricas, romanas e árabes" (SEVERO, 1916, p.54).

Debret atribuía aos jesuítas missionários a primazia na propagação da arquitetura portuguesa, enfatizando que "em geral respeitaram judiciosamente as exigências do clima e dos materiais existentes no país". Dizia também que “...deduziremos ser aos jesuítas missionários, já tão poderosos em 1526 sob João III, que se devem atribuir os primeiros grandes edifícios surgidos no Brasil e nos quais se propagou a arquitetura portuguesa." (1965, p.259)

Ora, Severo escreveria em 1916: "Aos jesuítas missionários, que se espalharam pelo vasto domínio colonial português, se devem os principais edifícios religiosos que se encontram nas possessões da Índia, da África e do Brasil”. (1916, p.50)

Na prancha 42 de "Voyage pittoresque et historique au Brésil" [FIGURA 1] está registrada uma pequena casa urbana representativa da arquitetura urbana carioca, constituindo "a quase totalidade das ruas e praças do Rio de Janeiro" - e uma casa de chácara, de planta bastante sui generis. Debret identificou influências romanas nesta residência [FIGURA 2] - tese de grande aceitação posterior destacando "sua analogia com as dos mouros na África e muito mais ainda com as casas antigas de Pompéia, cujos detalhes damos aqui para comparação."(1965, p.259) 

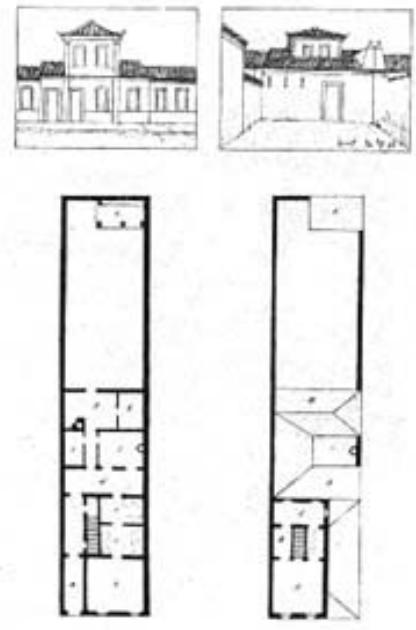
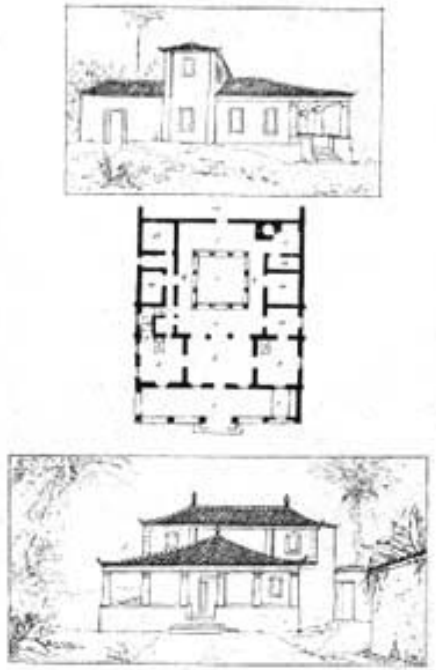

FIGURA 1 - Prancha 42, Plantas e elevaçōes de đuas pequenas casas brasileiras, de cidade e de campo, de Debret (1965, Vol. III). A esquerda, a casa urbana, de caracteristicas semelhantes às da arquitetura urbana colonial em geral. A direita, a casa rural, de planta sui generis em relacão aos padrōes coloniais, a que fol indevidamente generalizada por Ricardo Severo.

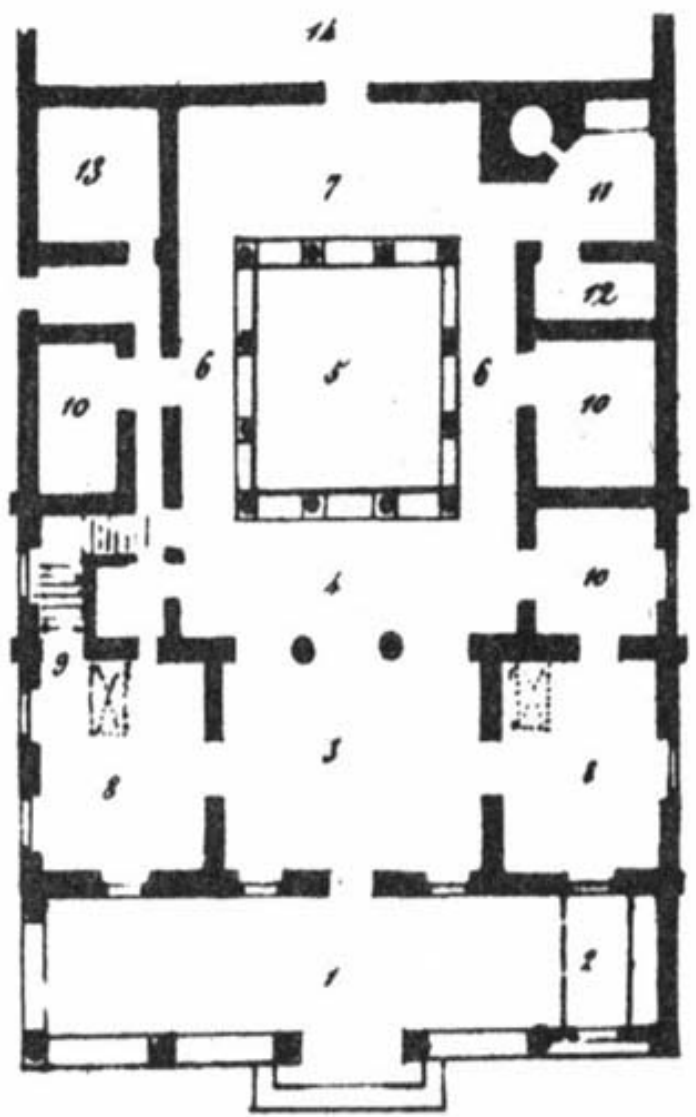

FIGURA 2 - Detaihe da planta da casa rural apresentada na FIGURA 1, na qual Debret identificou influências romanas, destacando "sua analogia com as dos mouros na Africa e muito mais ainda com as casas antigas de Pompeia..." Debret relacionou cada cómodo da casa com seu suposto correspondente pompeiano: a varanda (1) equivaleria ao protyrum; o oratório (2), ao ararium; a sala (3), ao tablinum ou exedra; a sala de jantar (4) correponderia ao triclinium; a área, ou pátio (5), ao impluvium; 0 atrium (6) conserva a denominação dos antigos; o corredor (7) seria o posticum; o quarto com janelas (8), o thal amus; a escada (9), a scala; o fogăo (11) seria a culina; a copa (12)، por ele denominada oficio, corresponderia a aporotheca: a quarto dos negros doentes (13) equivaleria ao hospicium; o pútio do galinheiro (14), a platéia. A alcova (10) teria seu nome derivado de alcoba, "palavra árabe que quer dizer tenda fechada, ou armário em que se dorme, tradiça perfeitamente aplicada aqui a virtual inexisténcia de moradias coloniais com tais caracteristicas, a interpretação 
Esta prancha foi apresentada durante a palestra de Ricardo Severo - que não só endossou a interpretação de Debret, como a generalizou indevidamente, afirmando que a casa de chácara de planta 'romana' reproduzida pelo pintor francês constituía um "tipo de casa que foi comum no Rio, segundo as notícias da época" (1916, p.65) - embora o pintor francês nada tivesse afirmado sobre o seu grau de representatividade como exemplar típico da arquitetura colonial.

Mas Severo não se restringiu às análises de Debret, desenvolvendo por sua conta associações entre elementos mouros, romanos e portugueses, que nos foram legados: comparou a gelosia ou rótula (denominada adufa em Portugal) ao

modelo que os romanos empregaram com a designação de transenna, em tudo semelhante às addafas árabes e aos moucharabiehs do Cairo. [Afirmou também que a "beira-saveira"] ...recorda os frisos e as arquivoltas em estalactites de edifícios moçárabes da Península lbérica... (1916, p.61 e p.57).

Tal como Severo, também José Mariano Filho - o epígono do Neocolonial no Rio de Janeiro - reiterou várias vezes a interpretação de Debret sobre o caráter "de fundo essencialmente romano" da arquitetura brasileira. Aos poucos, acrescentou contribuições próprias ao assunto, identificando, por exemplo, "direta influência da arquitetura rústica italiana (Toscana) do século XVI" na casa grande do engenho de Megaípe - referência provavelmente relacionada ao emprego de colunas toscanas na edificação ${ }^{9}$; também se referiu à utilização dos "módulos clássicos de proporção" mencionados no artigo Falsos Argumentos (1943, p.7). Ora, se é certo que encontram-se exemplares excepcionais em nossa arquitetura colonial, nos quais pode-se identificar recursos eruditos como a utilização de traçados reguladores, eles constituem antes a exceção do que a regra. Por outro lado, falar em "módulos clássicos de proporção" remete-nos imediatamente ao emprego das ordens clássicas - algo quase absolutamente ausente de nossa arquitetura colonial, seja como elemento estrutural, seja como recurso compositivo, exceto em alguns exemplares excepcionais.

Trata-se de uma linha de argumentação na qual Mariano Filho insistiria por muito tempo, pois reaparece, com ligeiras atualizações, na década de 1930, no artigo "Aumentando a confusão", originalmente publicado por volta de 1938:

As casas brasileiras - estou cansado de o afirmar desde 1921 - devem a placidez de sua fisionomia à impregnação do espírito romano, que se 
caracteriza pela proporção constante dos elementos de composição, e pela projeção geométrica retangular. (1943, p.124).

Aliás, a parcialidade de José Mariano Filho para com Debret era notória. Seu discurso na abertura do Salão de Belas Artes de 1924 - proferido na qualidade de presidente da Sociedade Brasileira de Belas Artes, cargo que ocupou na primeira metade da década de 1920 - resvalava em indisfarçáveis críticas de tons inequivocamente "neocoloniais" à Missão Francesa e seus objetivos, centrando elogios em Debret:

(...) A missão de 1816, contratada por Marialva, tinha o temerário propósito de implantar num país de raça portuguesa uma escola de arte francesa.

(...) A missão tem um grande programa a realizar, desde a pintura de gênero, ao fabrico da porcelana de arte, à maneira de Sèvres...

Mas ela se insula nas próprias idéias, monopoliza o movimento de arte no país, isola-se da própria nacionalidade como que fugindo-lhe ao contato deprimente.

(...) Debret porfia na documentação dos nossos costumes, de nossa indumentária. Mas o seu prestígio não ultrapassa os saraus pantagruélicos da corte.

Está fundada a escola onde vários alunos caboclos e mestiços se instruem na arte acadêmica da David...

Grandjean, que a meu ver é a figura central da missão, desdenha a contribuição da arquitetura nacional à qual Debret rende, todavia, homenagem. Grandjean tem o sentimento nobre da medida dentro dos cânones greco-romanos. Ele não veio aprender no país que o hospedava. Veio construir a sua arte. (In: PINHEIRO, 2005, p.6 e 70, grifos nossos).

Mas a autoridade de Debret não se restringia ao círculo neocolonial. Em seu livro Estudos Brasileiros, publicado no mesmo ano de 1924, o escritor modernista Ronald de Carvalho continuava a tomá-la como referência - ainda que a opinião do pintor francês sobre a arquitetura brasileira fosse muito menos impiedosa que a sua própria $^{10}$ :

Guardava o casario a mesma feição com que o viu e descreveu Debret, no correr do primeiro Império. Orlavam as ruas edifícios baixos, de fachada ridícula, pintados de colorações vivas, de amarelos, azuis e vermelhos estonteantes. Não deparavam eles o mais tênue sinal de gosto ou cuidado decorativo. Geralmente acaçapados e exíguos, arrimavam-se uns aos outros, unindo as frontarias até certa altura e, apartando-se, depois, numa teoria de telhados piramidais.

Excetuando-se as igrejas, só uma ou outra construção, a exemplo do palácio da Marquesa de Santos, da Academia de Belas-Artes ou do casarão da esquina da rua das Marrecas, mereciam particular atenção. (Capítulo Arte Brasileira, In: PINHEIRO, 2005, p.111). 
A persistência por quase um século da autoridade de Debret, a generalização apressada da pequena amostragem da arquitetura carioca por ele apresentada e a ausência de qualquer menção a outros estudos análogos, indica a falta de novas pesquisas relativas à arquitetura brasileira - que apenas começam a ser ensaiadas na década de 1920, com caráter ainda francamente operacional e subsidiário para com o movimento neocolonial.

\section{Repercussões das idéias de Ricardo Severo}

Já se adiantou que, embora partindo da obra de Debret, a contribuição específica de Ricardo Severo não se restringiu a ela. Seu principal objetivo, na conferência de 1916, era destacar a influência da arquitetura portuguesa - que conhecia bastante bem - em nosso meio. Comentou vários edifícios brasileiros e manifestou juízos de valor, como sua opinião francamente desfavorável sobre "a mesquinhez de proporções e pobreza de formas" que caracterizavam o estilo "barroco jesuítico" - termo recorrente desde então para designar nossa arquitetura religiosa dos primeiros séculos. Manifestou sua predileção pelos "belíssimos exemplares" do século XVIII existentes "no Rio e em algumas cidades do norte" preferência que, acrescida da arquitetura religiosa mineira, tornar-se-ia praticamente uma unanimidade ao longo da década de 1920 (1916, p.74-5), e concentraria os esforços preservacionistas mesmo após a criação do Serviço do Patrimônio Histórico e Artístico Nacional (SPHAN).

Considerando que "para construir arte tradicional são necessários elementos tradicionais" (1916, p.55-6), Severo utilizou um método de análise arquitetônica baseado na decomposição do edifício em seus elementos construtivos e decorativos. Bem de acordo com o conceito de arquitetura então predominante - em que a concepção espacial da obra como um todo é praticamente independente do tipo de ornamentação aplicado às superfícies parietais -, apresentou em sua conferência uma espécie de pré-inventário de elementos construtivos tradicionais da arquitetura brasileira: telhados, beirais, janelas, portas, rótulas, etc., analisados isoladamente [FIGURAS 3,4 e 5]. 


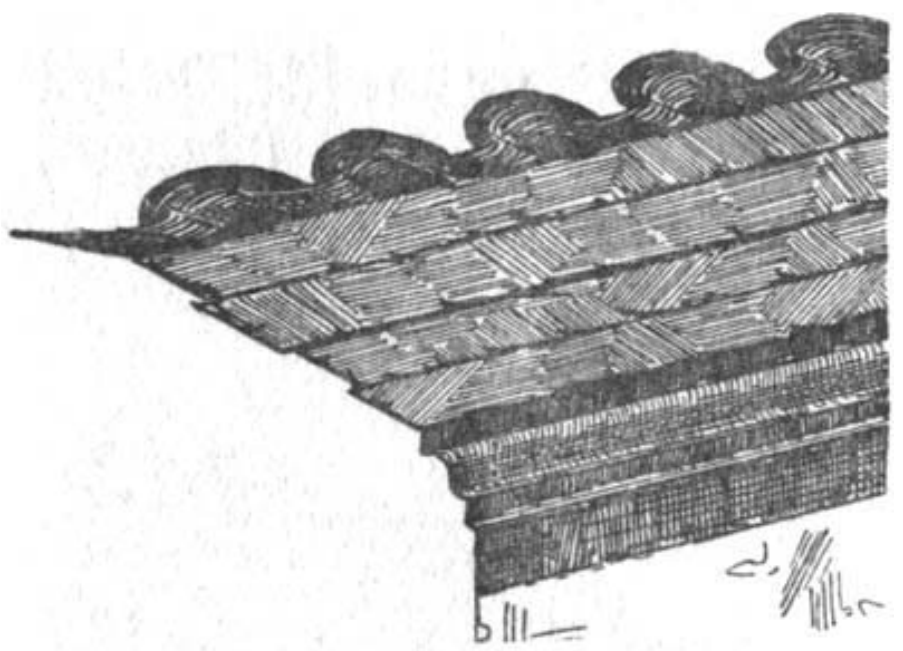

Fig. 6- Beiral com fôrro de madeira

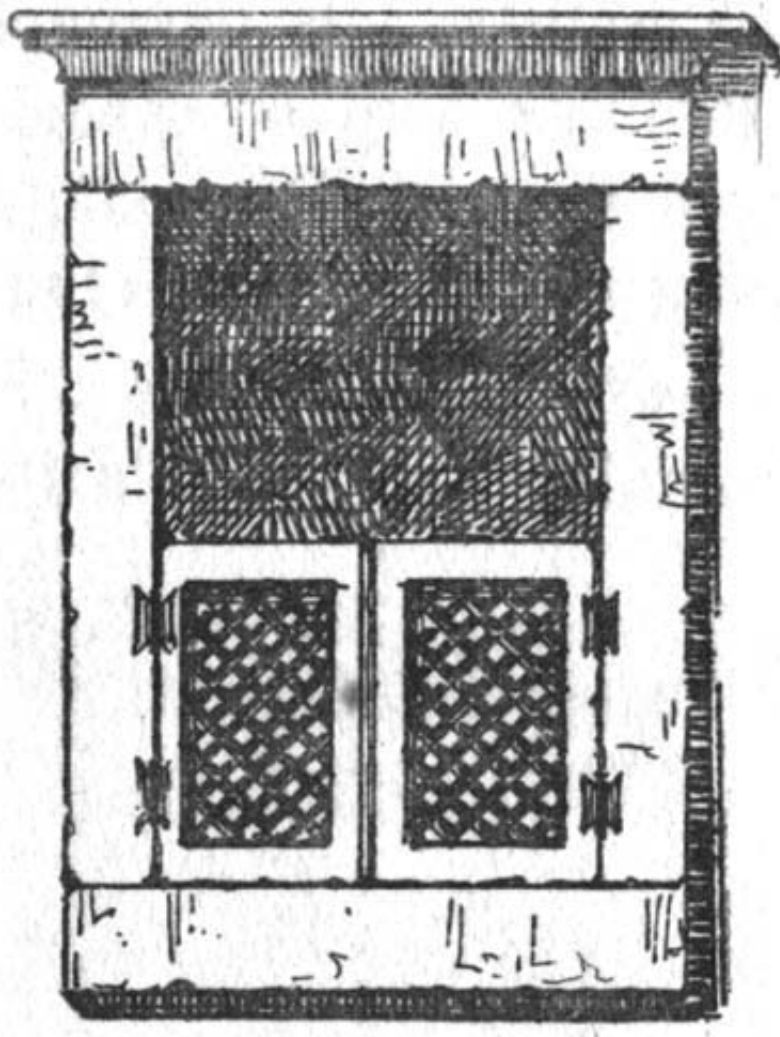

Fig. 11 - Janella de madeira com rotula 


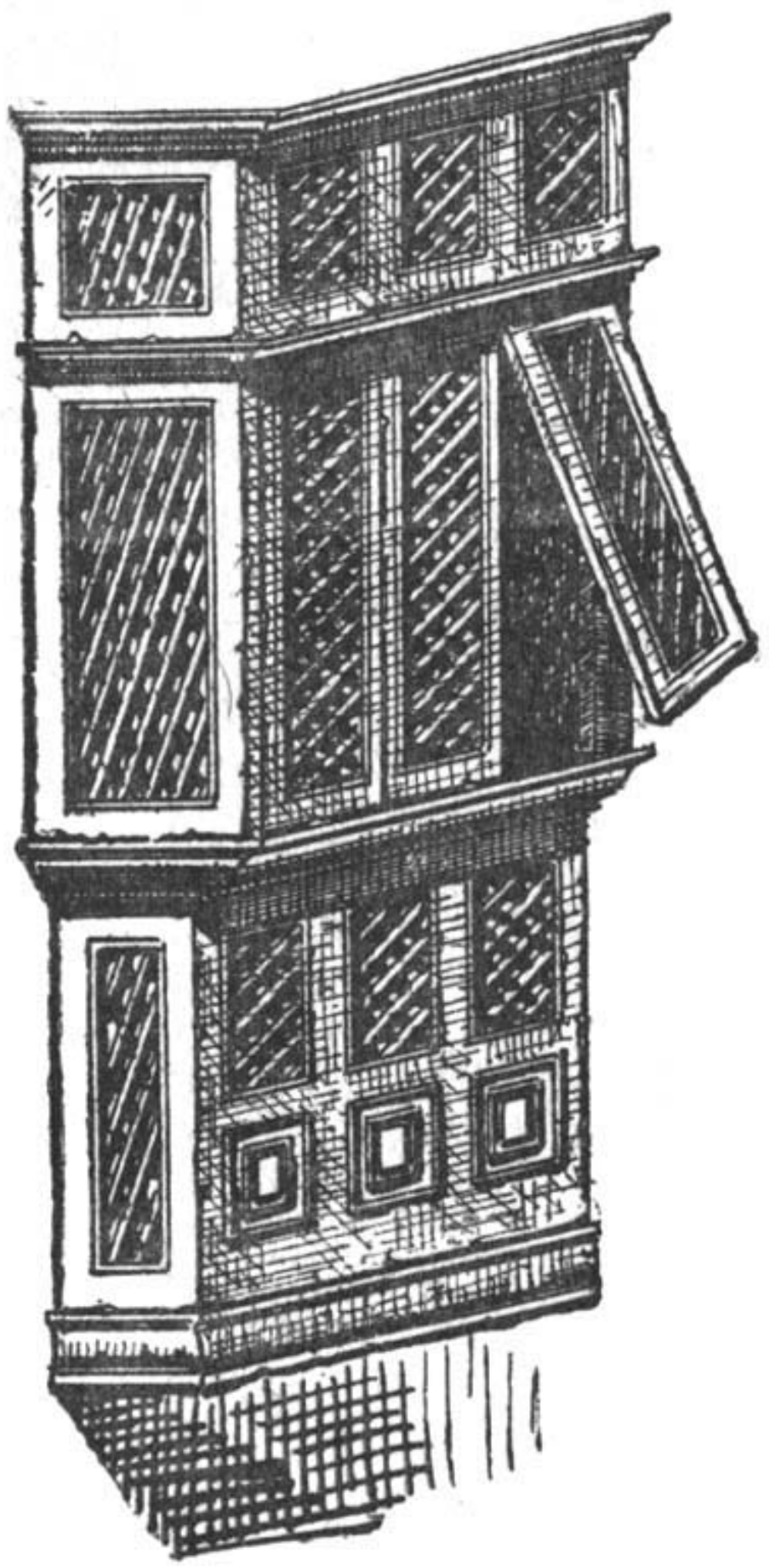

Fig. 21 - Gelosia recta - S. Paulo
1860-70.

FIGURAS 3,4 e 5 - Elementos construtivos tradicionais coloniais - beirais, janelas e muxarabis -apresentados desvinculadios de suas respectivas edificacōes por Ricardo Severo, na conferência A Arte Tradicional no Brasil (SEVERO, 1916, p. 59,63 e 1972) 
Tal metodologia - se é que podemos chamá-la assim - foi utilizada pelo pintor José Wasth Rodrigues, a quem Severo encomendou o levantamento iconográfico in loco de edificações coloniais brasileiras. Wasth Rodrigues realizou efetivamente inúmeras viagens pelo Brasil desde 1918, reunindo documentação que viria a tornar-se o livro "Documentário Arquitetônico", publicado originalmente em fascículos na década de $1940 .^{11}$

À maneira de Severo, a documentação coletada por Wasth Rodrigues privilegia a reprodução de elementos construtivos e decorativos isoladamente [FIGURA 6], ainda que alguns edifícios importantes tenham sido levantados em planta e elevação. O material denota claramente a intenção para a qual foi coletado, aliás explícita na introdução de Wasth Rodrigues: uma espécie de "livro de modelos" a inspirar a produção neocolonial daqueles anos. Mas, por sua publicação tardia, acabou não cumprindo tal desígnio - que parece ter ficado a cargo do álbum "Estilo colonial brasileiro: composições arquitetônicas de motivos originais", de 1927, concebido pelo desenhista italiano Felisberto Ranzini ${ }^{12}$ [FIGURA 7].

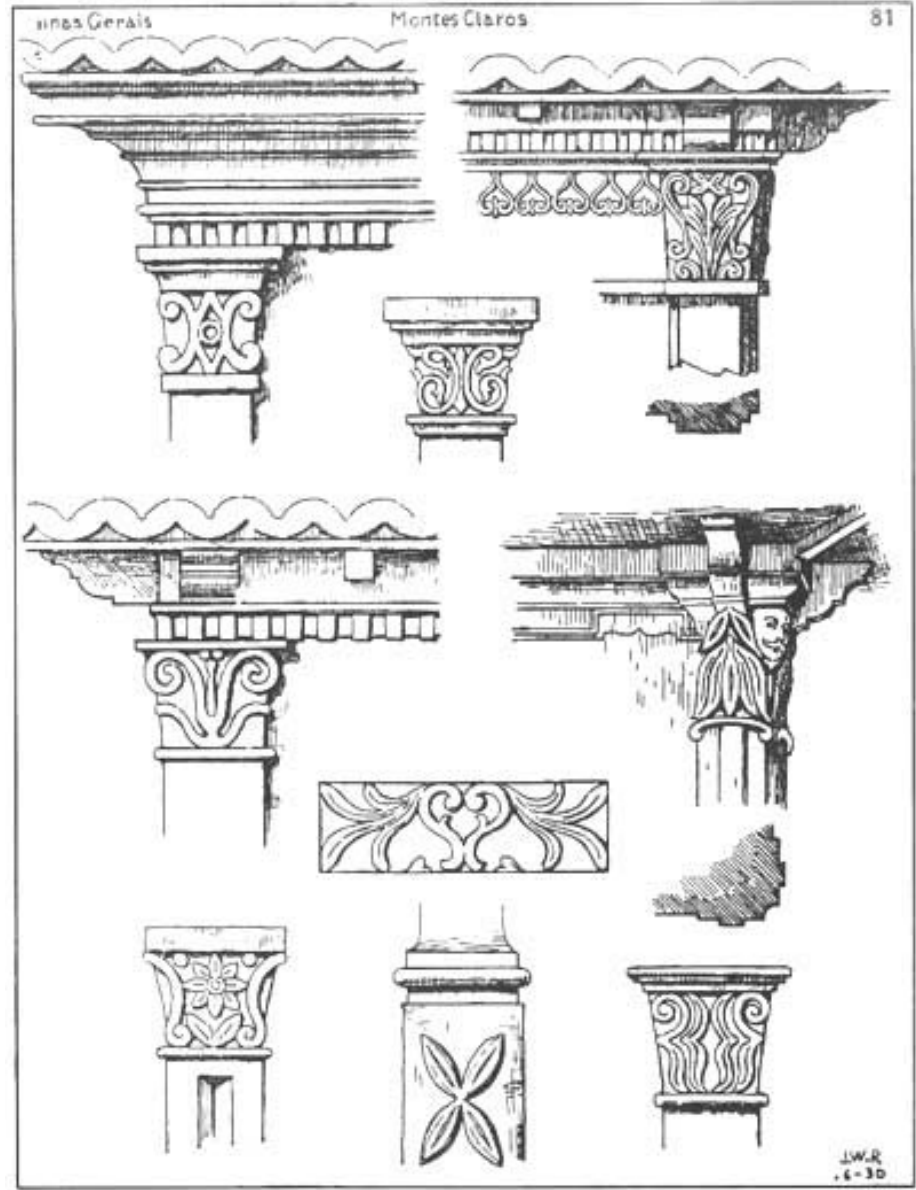

FIGURA 6 - José Wasth Rodrigues utilizou o mesmo esquema de Severo em seus levantamentos da arquitetura colonial brasileira, como se vê na estampa 81 .

Capitéis e outros detalhes de Montes Claros, Minas Gerais - de sua obra

Capitéis e outros detalhes de Montes
Documentário Arquitetônico (1979). 


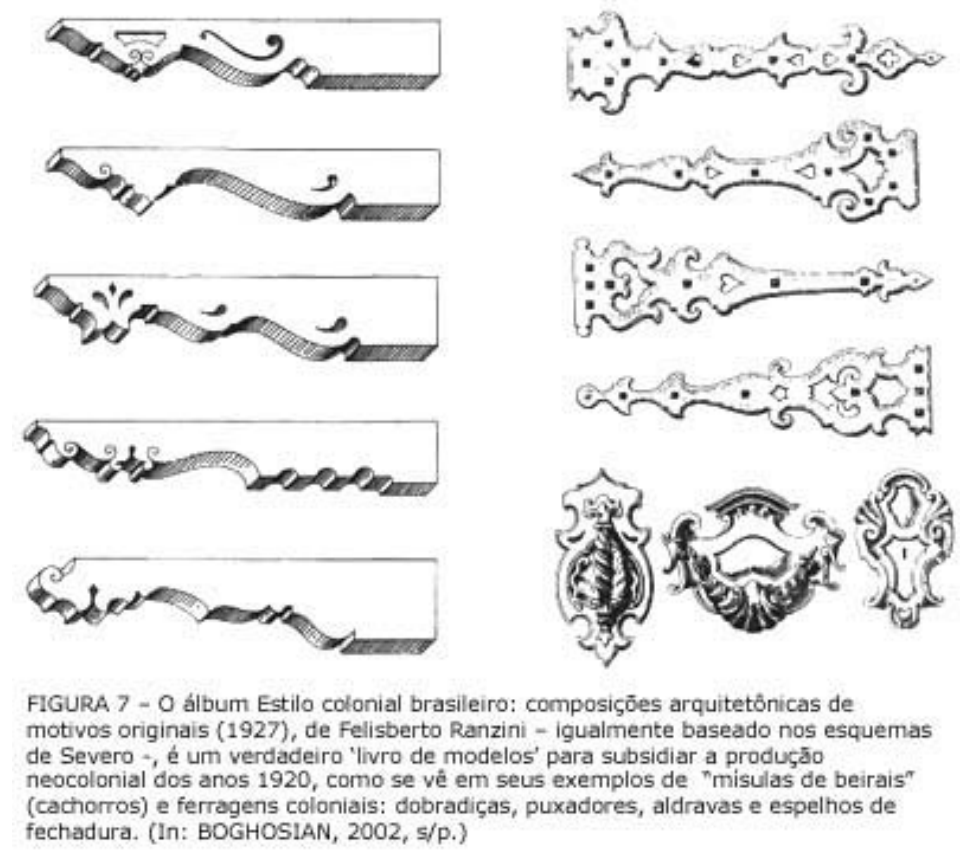

Não é improvável supor que tal abordagem da arquitetura tradicional brasileira tenha incentivado a retirada de elementos construtivos ou ornamentais de edifícios antigos, contribuindo para sua descaracterização e estimulando o comércio predatório de antiguidades. Ao menos, é o que se pode depreender dos termos utilizados pelo deputado José Wanderley de Araújo Pinho em seu projeto de lei federal apresentado em 1930 e relativo a "todas as coisas imóveis ou móveis a que deva estender a sua proteção o estado, em razão de seu valor artístico, de sua significação histórica ou de sua peculiar e notável beleza”. Nesta peça jurídica, Pinho faz referência explícita à proteção de elementos construtivos como:

as cimalhas, os frisos, arquitraves, portas, janelas, colunas, azulejos, tetos, obras de marcenaria, pinturas murais, e quaisquer ornatos que possam ser retirados de uma edificação para outra e que, retirados, mutilem ou desnaturem o estilo do imóvel ou a sua unidade, qualquer que seja o material de que se acham constituídos, e ainda quando tal mutilação não prejudique aparentemente o mérito artístico ou histórico do imóvel a que estavam aderidos...(MEC / SPHAN / PRÓ-MEMÓRIA, 1980, p.79-80).

O projeto de Wanderley Pinho, que apresenta avanços indiscutíveis em relação a iniciativas anteriores ${ }^{13}$, é o primeiro a manifestar consciência de que o bem cultural é um todo indissociável, e que o colecionismo de peças oriundas de edifícios antigos - acessórias ou constitutivas - poderia estimular a dilapidação do patrimônio. Aliás, deve-se ressaltar que tanto Ricardo Severo quanto José Mariano Filho estavam entre os maiores colecionadores de antiguidades do período. ${ }^{14}$ 
Em 1926, o jornal O Estado de São Paulo (OESP) realizou um inquérito sobre Arquitetura Colonial, entrevistando alguns dos mais destacados defensores do movimento neocolonial ${ }^{15}$. Em seu depoimento, José Wasth Rodrigues demonstrou preocupação pioneira em relação às demolições e descaracterizações sofridas por exemplares do patrimônio cultural brasileiro, sugerindo:

a fundação de uma Sociedade ou Comissão de Arquitetos com plenos poderes junto aos governos e às Cúrias para embargar as demolições e impedir que as restaurações sejam feitas com o sacrifício da "fisionomia característica" do edifício. Em minhas viagens tive ocasião de ver, com espanto, templos góticos e bizantinos exatamente onde se levantavam, havia pouco, antigas igrejas coloniais". (OESP, 16/04/1926, p.4).

Este interesse pela arquitetura do passado, que se estende até a defesa de sua preservação, é pouco usual no período, e não encontrava eco nem mesmo em Ricardo Severo, que jamais externou qualquer preocupação a respeito.

Outro importante protagonista do período que também parece ter sido fortemente impressionado pelas idéias de Severo é Mário de Andrade, cujos primeiros artigos sobre arquitetura - a série de artigos sob o título "A Arte religiosa no Brasil", publicados em 1920 na Revista do Brasil' ${ }^{16}$ - bem como as viagens que empreendeu para escrevê-los, parecem claramente motivados por elas. Tal como Wasth Rodrigues, Mário está certamente entre os primeiros artistas e intelectuais do período a conhecer in loco antigas cidades brasileiras. Sua primeira viagem a Minas Gerais foi realizada nas férias de junho de 1919 (KRONBAUER, 1993, p.11); mais tarde, em 1924, Mário voltaria a Minas Gerais em companhia do escritor francês Blaise Cendrars e de alguns amigos modernistas.

Nas crônicas resultantes desta primeira viagem pode-se vislumbrar a indiscutível influência de Severo - mas também o Mário de Andrade que nos é familiar, com seus costumeiros, mas sempre surpreendentes, laivos de ousadia e originalidade. Em alguns trechos, com efeito, Mário sentia-se à vontade para discordar de algumas afirmações do engenheiro português ${ }^{17}$ - além de, com grande desenvoltura, aventar hipóteses sobre o caráter pioneiro de que se revestiu 0 barroco entre nós. A mais significativa destas hipóteses - que parece ter alcançado grande repercussão posterior - diz respeito ao "caráter muito mais nacional" que o barroco teria assumido no Brasil (In: KRONBAUER, 1993, p.78-9). É realmente de se perguntar se alguém já havia até então ressaltado o caráter genuinamente 
nacional da arquitetura religiosa mineira, independentemente de quaisquer associações históricas com a Inconfidência.

Muito mais arrojada - embora indicativa da insipiência dos conhecimentos de Mário sobre o assunto - é sua afirmação de que, em Minas Gerais, o estilo barroco, pela primeira vez, "passa da decoração para o próprio plano do edifício", tornandose, assim, "um verdadeiro estilo" equiparável ao egípcio, ao grego, ao gótico: "E é para nós motivo de orgulho bem fundado que isso se tenha dado no Brasil" (Idem, p.79-80).

Esta vinculação inicial de Mário de Andrade a Ricardo Severo e ao neocolonial - do qual revelou-se entusiasta no início da década de 1920 - parece explicar a presença do estilo na seção de arquitetura da Semana de Arte Moderna Semana de 1922, através de um projeto elaborado pelo arquiteto polonês Georg Przyrembel. ${ }^{18}$

Também pode-se vincular às idéias e iniciativas de Ricardo Severo a realização das "excursões técnicas" promovidas por Alexandre Albuquerque ${ }^{19} \mathrm{com}$ seus alunos do curso de engenheiro-arquiteto da Escola Politécnica de São Paulo, destinadas a cidades como Itanhaém, Ouro Preto, Tiradentes e Congonhas do Campo. Essas viagens - realizadas entre os anos de 1921 e $1925^{20}$, "sempre que permitiram as verbas destinadas a exercícios práticos em nossos escassos orçamentos escolares" (OESP, 1926, p.4; ALBUQUERQUE, 1930, p.62) -, revestiram-se de um caráter oficial pioneiro, uma vez que eram realizadas com recursos da dotação orçamentária da escola. Albuquerque assim se pronunciou a respeito:

\footnotetext{
Para estimar o colonial é preciso conhecê-lo. É necessário viajar e longamente meditar em frente de cada monumento.

(...) Quem já viajou pelas nossas cidades coloniais, quem conhece Ouro Preto, Mariana, Congonhas, São João del Rey, Tiradentes, para citar apenas algumas, sabe distinguir a arte portuguesa aclimatada, da que floresceu no velho mundo. Neste exame, a crítica é, às vezes, influenciada pelo patriotismo lusitano ou pelo bairrismo nativista. (ALBUQUERQUE, 1930, p.59 e p.61).
}

Nas excursões, os alunos eram incentivados a fazer desenhos e levantamentos in loco de edifícios importantes, parte dos quais foi mais tarde publicado no Boletim do Instituto de Engenharia (n.63, ago 1930, p.59-62), por ocasião do $2^{\circ}$ centenário do batismo de Aleijadinho, à guisa de "contribuição que 
trazem os arquitetos da Escola Politécnica, às festas comemorativas do bicentenário do Aleijadinho". [FIGURAS 8 e 9]
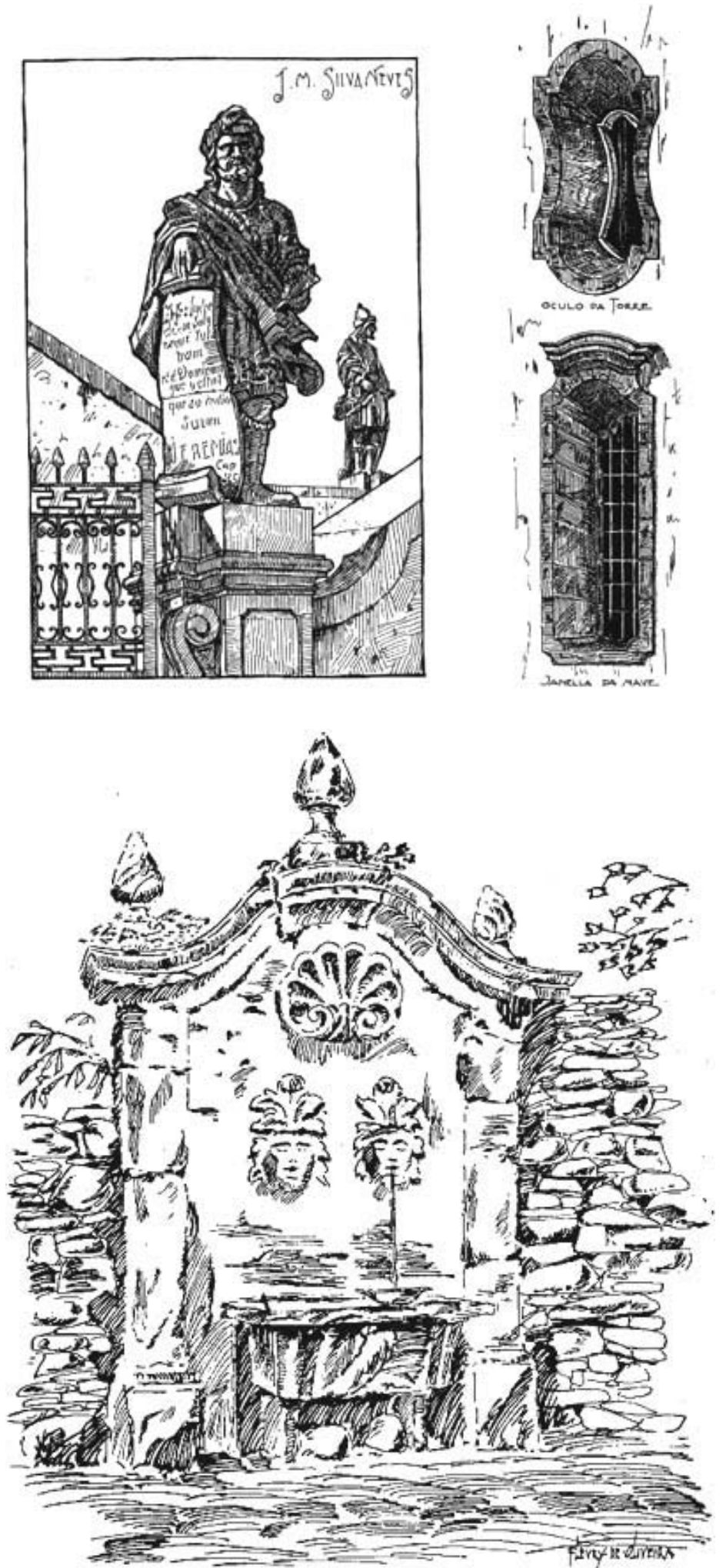

FIGURAS 8 e 9 - Desenhos realizados pelos alunos de Alexandre Albuquerque nas excursōes técnicas por ele promovidas às cidades históricas mineiras. FIGURA 8: à esquerda, o Profeta Jeremias, obra do Aleijadinho em Congonhas do Campo, desenhado por José Maria da Silvá Neves; à direita, vãos da Igreja de S. Francisco de Assis em Ouro Preto, por Cardim Filho. FIGURA 9: Chafariz em Ouro Preto, desenhado por Fleury Filho. In: Boletim do Instituto de Engenharia 63, ago 1930, p.59-62. 
Em sua entrevista ao jornal OESP como parte da série Arquitetura Colonial (OESP, 17/04/1926, p.4), Alexandre Albuquerque também deixou transparecer ecos de Debret ao discorrer sobre as inúmeras influências - romanas, árabes - presentes na arte colonial, privilegiando a "ligação lógica" entre "o solar português com a entrada e o saguão, e casa romana, com o 'protyrum' e o 'atrium'”.

Nesta entrevista, Albuquerque reafirmou a importância de "desenvolver 0 conhecimento mais perfeito da arquitetura colonial..." e, tal como Wasth Rodrigues, manifestou preocupações concretas com a defesa do patrimônio histórico e artístico nacional, elencando mesmo um conjunto de medidas práticas nesse sentido: promover viagens de estudantes de arquitetura pelo interior do Brasil,

\begin{abstract}
por serem as viagens às cidades históricas o melhor compêndio de arquitetura colonial; constituir missões científicas e artísticas para coletar documentação iconográfica (desenhos e pinturas); dar preferência ao barroco colonial na confecção de certos edifícios públicos em que não se explica o ecletismo atual; nacionalizar ou reivindicar para o patrimônio público certos monumentos verdadeiramente históricos e de valor incontestável como obras de arquitetura colonial, algumas das quais já foram atingidas por esse vandalismo utilitário e demolidor das nossas melhores tradições; e impedir a evasão de obras de arte para o exterior. (OESP, 17/04/1926, p.4).
\end{abstract}

Em que pese o pioneirismo de algumas das propostas de Alexandre Albuquerque, não se pode deixar de notar a contradição entre as medidas preconizadas e sua participação nas obras da nova Catedral de São Paulo - que substituía a Sé colonial - a partir de 1919, após a morte de George Krug.

\title{
A contribuição de José Mariano Filho
}

Talvez a principal contribuição de José Mariano Filho para o desenvolvimento de uma história da arquitetura brasileira resida na sua insistência em apontar a falta generalizada de "obra escrita" sobre nossa arquitetura tradicional, denunciando ao mesmo tempo que "...as livrarias estão repletas de livrecos e álbuns, contendo centenas de projetos de bungalows vulgaríssimos..." (1943, p.8). ${ }^{21}$

De fato, Mariano Filho é certamente o primeiro - senão o único - dentre os partidários do neocolonial a criticar o caráter fantasioso da maioria de seus exemplares $^{22}$, ressalvando, ao mesmo tempo, a falta de estudos sistemáticos sobre o assunto, agravada pela inexistência de "uma cadeira de cultura artística e histórica 
dedicada à arte nacional" (Artigo Falsos Argumentos. Idem, p.7). Seu papel nesse sentido foi destacado por Manuel Bandeira:

O meu amigo José Mariano anda agora com um trabalho danado para mostrar que nada disso é "casa brasileira", que não basta azulejo e telha curva para fazer arquitetura brasileira, que os profiteurs da moda (porque hoje é moda ter o seu "bangalô colonial") sacrificaram inteiramente o espírito arquitetônico da renovação a exterioridades bonitinhas. (BANDEIRA, 1930, p.93-6, grifo nosso).

Visando suprir a carência de estudos e de repertório sobre a arquitetura tradicional brasileira por ele apontada, José Mariano Filho tomou a iniciativa de patrocinar, através da Sociedade Brasileira de Belas Artes (SBBA), bolsas de viagem concedidas a jovens arquitetos ou estudantes de arquitetura às cidades mineiras do ciclo do ouro. Assim foram realizadas as viagens de Nestor de Figueiredo a Ouro Preto (noticiada no Correio da Manhã, 23/02/1924, p.1); de Nereu Sampaio a Congonhas do Campo, e de Lúcio Costa a Diamantina - todas no início de 1924. [FIGURA 10]

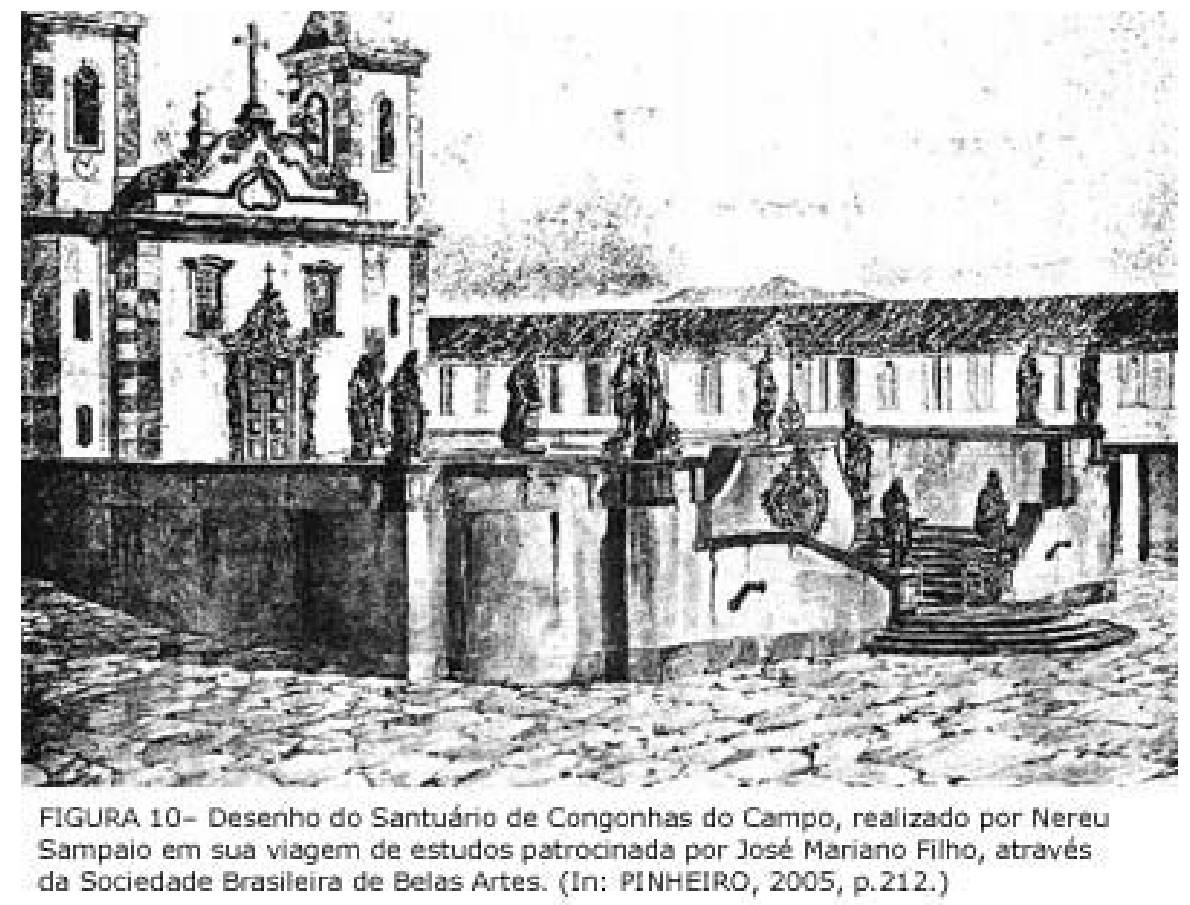

Nessa viagem a Diamantina, o então jovem estudante Lúcio Costa pôde constatar a diferença entre a arquitetura lá encontrada e o "colonial de estufa" então realizado no Rio de Janeiro, conforme consignou no artigo "Considerações sobre nosso gosto e estilo", publicado em A Noite, 18/06/1924 (In: SILVA, 1991, p.173). ${ }^{23}$ Não será talvez descabido imaginar que a ascendência de que o arquiteto sempre gozou junto ao corpo técnico do SPHAN, desde o início de sua carreira naquele 
órgão, esteja ligada aos conhecimentos adquiridos através de contatos tão precoces e diretos com exemplares concretos da arquitetura colonial brasileira.

A iniciativa de José Mariano influenciou outros arquitetos a fazerem o mesmo, como Raphael Galvão, que,

na pesquisa de motivos arquitetônicos tradicionalistas, viajou por conta própria o Espírito Santo e o interior de Minas Gerais, tendo recolhido copioso material, nas cidades de Congonhas do Campo, São João del Rey e Sabará, e alguns elementos em Vitória (COSTA, 1927, p.261).

O próprio Lúcio Costa realizou, por conta própria, outras viagens a Minas Gerais naqueles anos: em 1928, vêmo-lo "veraneando à sua moda", conforme suas palavras, no Caraça e em Ouro Preto, ocasião em que realizou o projeto vencedor do concurso para a Embaixada Argentina - em estilo Missões (Entrevista a O Jornal, 28/04/1928; In: SANTOS, 1960, p.27-8).

Autores como Paulo Santos supõem que tais viagens despertaram a atenção do governo mineiro para com a questão patrimonial (SANTOS, 1960, p.16, nota 42). Seja como for, é fato que, em julho de 1925, o governador de Minas Gerais, Mello Viana, montou uma comissão para elaborar um anteprojeto de lei relativo à proteção do patrimônio histórico e artístico brasileiro. Embora a iniciativa não tenha obtido êxito - tal como suas antecessoras -, ela deve ter constituído a base para a criação, no ano seguinte (1926), da Inspetoria Estadual de Monumentos Históricos em Minas Gerais. ${ }^{24}$

Curiosamente, entretanto, o tema da defesa do patrimônio histórico e artístico nacional não chegou a sensibilizar os jovens beneficiados pelas bolsas de estudo da SBBA, que jamais se manifestaram a respeito, ao menos naqueles anos ${ }^{25}$ - observação que se estende, aliás, ao próprio José Mariano, cujos primeiros artigos a mencionar a demolição de importantes monumentos arquitetônicos datam de $1928^{26}$.

Prosseguindo em sua campanha para promover o estudo da arquitetura colonial brasileira, com o fito de contribuir para o desenvolvimento do estilo Neocolonial, José Mariano Filho passou a mirar alvo mais ambicioso: a diretoria da Escola de Belas Artes do Rio de Janeiro - posição à primeira vista inatingível, dada sua formação em medicina. De fato, Mariano Filho vinha claramente empreendendo esforços de aproximação junto aos meios ligados à arquitetura e à própria instituição desde o início da década de 1920. Valia-se, para tanto, de expedientes vários, 
facilitados pela sua condição de presidente da Sociedade Brasileira de Belas Artes condição que naturalmente o colocava em posição privilegiada em relação ao corpo docente e discente da ENBA, composto majoritariamente de artistas em geral, sempre à procura de mecenas generosos. Entre tais expedientes, contavam-se, além das já citadas viagens de estudo, doações freqüentes - geralmente de pinturas - para o acervo da Escola, e a promoção de concursos de arquitetura ${ }^{27}$.

Com efeito, como parte de sua atuação proselitista pró-neocolonial, José Mariano Filho promoveu vários concursos de arquitetura, amplamente divulgados pela imprensa: o "Prêmio Heitor de Mello" ou "Prêmio Casa Brasileira", destinado a projetos residenciais, realizado em 1921 e reeditado em 192328; foi realizado também - provavelmente em 1922 - o "Concurso José Mariano Filho", dirigido ao projeto de elementos para jardim ${ }^{29}$.

É, aliás, um traço característico da cultura brasileira do início do século a assiduidade com que os intelectuais do período compareciam nas páginas dos periódicos da época; certamente um sintoma de seu reduzido número. Mariano Filho soube aproveitar-se desta situação, utilizando-se amplamente da imprensa para disseminar suas idéias e angariar adeptos ${ }^{30}$.

Seja como for, o fato é que, não obstante as dificuldades a enfrentar, José Mariano Filho logrou ser nomeado Diretor da Escola de Belas Artes pelo Ministro da Justiça Vianna do Castello em 1926 - o que evidencia seu prestígio entre as elites dirigentes do país ${ }^{31}$. A nomeação foi justificada pelas alegadas intenções do ministro de proceder a uma reforma administrativa na instituição, na qual colocava-se a antiga reivindicação do aumento dos vencimentos dos professores.

Nesta privilegiada posição, que assumiu em maio de $1926^{32}$, Mariano Filho procurou pôr em prática o programa de ação do movimento neocolonial, que ele próprio acabara de formular, pouco antes de sua nomeação para a diretoria na ENBA - e que consistia "...antes de tudo, no reconhecimento e seleção do vocabulário característico do estilo tradicional brasileiro." (Depoimento na série Arquitetura Colonial, in OESP, 21/04/1926, p. 4)

Entretanto, a nomeação de um diretor alheio ao corpo docente e de formação completamente estranha aos diplomas fornecidos pela Escola só poderia suscitar muita animosidade - que se manifestou já na primeira reunião presidida por ele, na qualidade de Diretor em Comissão (10/09/1926) ${ }^{33}$, e que parece ter persistido ao longo de todo o seu mandato. 
A despeito de tais condições adversas, Mariano Filho aproveitou-se das circunstâncias peculiares que - além da questão dos vencimentos dos professores supostamente justificavam sua nomeação: uma reforma curricular e administrativa na Escola, há tempos reivindicada pelo corpo docente.

Sugeriu imediatamente a criação de novas disciplinas para os vários cursos, tais como: Estatuária; Física Experimental e Industrial; e História da Arte Brasileira, a serem ministradas em módulos de 80 lições anuais. Propôs, ainda, uma cadeira de Filosofia da Arte, em 24 conferências. É evidente sua intenção de introduzir o estudo da arte colonial brasileira no currículo da escola, providência há muito reclamada por ele, como vimos.

Mas a iniciativa não foi aprovada. Em seu parecer contrário relativo à questão, Gastão Bahiana argumentou, no caso específico da disciplina de História da Arte Brasileira, que seu conteúdo poderia ser distribuído entre as cadeiras de História da Arte e de História e Teoria da Arquitetura, pois

\begin{abstract}
a Arte Brasileira (a não ser que se queira entrar em minúcias inúteis) não comporta um estudo em $\mathbf{8 0}$ lições; algumas aulas dentre as 160 de História da Arte e as 160 de História e Teoria da Arquitetura, serão de certo suficientes para expor o histórico da vida artística nacional (In PINHEIRO, 2005, p.72, grifos nossos). ${ }^{34}$
\end{abstract}

Assim, a investida de José Mariano para a criação da disciplina História da Arte Brasileira - claramente inserida em sua campanha neocolonial, e principal meta como diretor da ENBA - não foi bem sucedida ${ }^{35}$. Ao que parece, havia consenso sobre a suficiência dos parcos conhecimentos então disponíveis sobre arquitetura brasileira entre o corpo docente da ENBA - o que, do ponto de vista adotado no presente trabalho, é indício da pequena importância então conferida ao nosso patrimônio histórico e artístico.

Pouco depois, a partir de fevereiro de 1927, instaurou-se uma polêmica entre Mariano Filho e a Congregação da escola a respeito do concurso de livredocência do Prof. Rodolfo Amoedo, que, ao que se pode depreender da leitura das atas, perdera o prazo para requerer a realização do concurso, devido a dúvidas sobre as disposições do regimento. Embora a Congregação se mostrasse disposta a resolver o problema em favor do professor, o diretor não concordou com esta posição, propondo-se a submeter o caso à apreciação do Ministro da Justiça, a quem estava afeita a questão (PINHEIRO, 2005, p 73). 
A polêmica sobre a livre-docência prolongou-se por um mês, e, embora os registros das atas não forneçam uma seqüência completa e inteligível dos acontecimentos que se seguiram - além da impossibilidade de saber exatamente o que estava por detrás das moções apresentadas e dos apoios manifestados -, o fato é que, na sessão seguinte (12/05/1927), José Mariano foi destituído do cargo de Diretor $^{36}$. A sessão seguinte (15/06/1927) já foi presidida por um novo diretor, o Prof. José O. Correia Lima (Idem, ibidem).

Como se vê, o curto mandato - aproximadamente um ano - de José Mariano Filho na diretoria da ENBA pautou-se pela animosidade entre a sua pessoa e a Congregação da escola, suscitada desde o início pela sua condição de elemento estranho ao corpo docente, e agravado por fatores vários, desde a mudança de orientação que procurou discretamente promover, até divergências quanto ao sistema de mérito vigente na carreira docente ${ }^{37}$. Tudo, evidentemente, perpassado pela orientação europeizante e academicista que caracterizava o ensino na instituição.

Deve-se ressaltar que, em meio à polêmica que acabaria por alijá-lo da diretoria, Mariano Filho não hesitou em lançar mão de sua fortuna pessoal para angariar as simpatias do corpo docente da ENBA, utilizando recursos como a doação de verbas para a aquisição de livros para a biblioteca, num total de quatro contos e duzentos mil réis, quantia à época significativa (PINHEIRO, 2005, p.74).

Não é de surpreender, portanto, que, após sua destituição, José Mariano tenha retomado a prática da promoção de concursos de arquitetura tradicional. Em 1929 - certamente inspirado pela proximidade do Bi-Centenário do Aleijadinho, a ser comemorado em 1930 -, propôs à congregação da ENBA a instituição, durante três anos, de

um prêmio anual de 3 contos de réis (3:000\$000) em favor do aluno que haja terminado o curso de arquitetura com as melhores notas escolares, para o fim especial de coligir nas velhas cidades de Ouro Preto, Congonhas do Campo, São João d'El Rei e Mariana, documentação de detalhes arquitetônicos e ornamentais da obra do genial artista mineiro Antônio Francisco de Lisboa (alcunhado o Aleijadinho). Os elementos e detalhes colhidos, que terão caráter de levantamentos devidamente cotados, na escala que a douta Congregação se dignar estabelecer, constituirão um arquivo especial para uso dos professores, estudantes e arquitetos brasileiros, sob a denominação de 'Arquivo Araújo Vianna' em homenagem ao grande mestre, cuja voz primeiro se levantou, no recinto da EBA, em defesa da arte colonial brasileira, e dos humildes mestres que a criaram.

[Justificava tal iniciativa por ter constatado, durante o período em que dirigiu a escola], não possuir este alto instituto de ensino artístico, 
documentação alguma referente à arquitetura brasileira da fase colonial, cuja análise, e compreensão, me parecem indispensáveis à elaboração do estilo arquitetônico nacional (Idem, p.75).

Sua proposta dividiu as opiniões do corpo docente; houve quem, como o Prof. Flexa Ribeiro, declarasse "que the acusavam de ser contrário ao 'estilo colonial', o que não era positivamente verdade, uma vez que não poderia ser contra, uma coisa que não existe". Gastão Bahiana sugeriu ampliar o objetivo do prêmio, "não só porque, a par do artista cognominado "o Aleijadinho" trabalharam outros, mas até porque difícil ou quase impossível, se tornaria a tarefa, de distinguir ou separar das demais, a obra daquele artista." Outros, como o diretor Correa Lima e o professor Chabréo, manifestaram-se imediatamente favoráveis, e a proposta foi aprovada. Foram igualmente tomadas as providências para pô-la em prática, pois, em carta datada de 27 de maio de 1930, José Mariano Filho comunicava estar à disposição da escola a importância de 9:000\$000 referente ao prêmio que instituiu (Idem, ibidem). Porém, os tumultuados eventos políticos do ano de 1930 - e sua repercussão na ENBA - abortaram a realização do concurso.

Como se vê, a falta de unanimidade em torno de iniciativa meritória, que em nada oneraria o orçamento da escola, evidencia não só a animosidade em relação a Mariano Filho, como também o estreito academicismo que imperava entre o corpo docente da ENBA, e seu corolário imediato: o menosprezo para com o patrimônio histórico e artístico brasileiro.

\section{O Aleijadinho e a preeminência de Minas no panorama preservacionista}

A proposta de José Mariano Filho constitui mais uma evidência do destaque que começa a ser conferido ao Aleijadinho como o maior artista colonial ao final da década de 1920. Com efeito, em 1928 - ano em que fora criada a Inspetoria de Monumentos Históricos de seu estado natal - o escritor pernambucano Manuel Bandeira dedicou alguns artigos ao patrimônio mineiro, em que, a par de tecer resignadas considerações a respeito da descaracterização de importantes cidades brasileiras - como Salvador e Olinda -, destacava a importância de Ouro Preto, pois "ela será sempre a capital do passado de Minas, a aparição desse passado tão cheio de memórias heróicas, tão rico de tradição artística". Aproveitou a oportunidade para denunciar a escassez de estudos sobre o expoente máximo da arte colonial brasileira: 
Depois de Saint-Hilaire, só uma pessoa, ao que me consta, ocupou-se de tão extraordinário artista, dando-se ao trabalho de indagações e pesquisas de primeira mão sobre a sua vida e obra. Foi o publicista mineiro Rodrigo José Ferreira Bretas, bisavô do meu querido amigo Rodrigo Mello Franco de Andrade.

(...) Daí para cá não se tem feito senão repetir o que escreveu Bretas. (Artigo O Aleijadinho. In: PINHEIRO, 2005, p.9, grifos nossos).

Num misto de exortação e provocação aos intelectuais brasileiros, Bandeira mencionou também a intenção manifestada de um lado, pelo escritor francês Blaise Cendrars; e de outro, pelo epígono do neocolonial, José Mariano Filho - que descreveu como "um apaixonado de nossas tradições" - de escrever a respeito do genial artista mineiro.

Em resposta, Mário de Andrade - de resto, grande amigo do escritor pernambucano - escreveu, ainda em 1928, "O Aleijadinho e sua posição nacional", em que, a par de exaltar a figura do mulato brasileiro, retomava algumas idéias esboçadas nas crônicas de 1920 acerca do caráter nacional da arquitetura mineira. Em 1929, é a vez de Lucio Costa publicar o artigo "O Aleijadinho e a arquitetura tradicional' em $O$ Jornal, edição especial dedicada a Minas Gerais. Nessa oportunidade, Costa procurou ressaltar as características genéricas essenciais da arquitetura brasileira, em detrimento da excepcionalidade virtuosística da obra do Aleijadinho.

Também em 1929, a revista llustração Brasileira publicou edição comemorativa do $137^{\circ}$ ano do sacrifício de Tiradentes, ressaltando as medidas então tomadas pelo governador Antônio Carlos “...no intuito de salvá-las [as relíquias históricas de Ouro Preto] da ruína...” (In: PINHEIRO, 2005, p.36) ${ }^{38}$.

Em 1930 - o ano de comemoração do Bi-Centenário de Nascimento do Aleijadinho - vários eventos foram realizados e amplamente divulgadas pela imprensa, nos quais José Mariano Filho - invariavelmente apresentado como "antigo diretor da Escola Nacional de Belas Artes" - teve destacada participação, pronunciando a conferência Mestre Aleijadinho e sua obra, "do púlpito da Igreja de São Francisco de Assis, de Ouro Preto, em 29 de agosto de 1930" (O Cruzeiro, edição comemorativa do Bicentenário do Aleijadinho. In: PINHEIRO, 2005, p.40). Esta palestra deu origem ao livro Antônio Francisco Lisboa, publicado por ele em 1945 - numa tardia corroboração das palavras de Bandeira. 
Seja devido à efeméride relativa ao maior artista colonial brasileiro, seja pela repercussão que o movimento neocolonial lograra alcançar então, o fato é que, no início da década de 1930, ganham corpo as manifestações de preocupação sobre o patrimônio de Ouro Preto, berço da Inconfidência Mineira e, portanto, da nacionalidade - preocupações que estão na base da promulgação do Decreto no. 22.928, de 12 de julho de 1933, instituindo a cidade de Ouro Preto em Monumento Nacional, e que certamente confluíram para a criação do Serviço do Patrimônio Histórico e Artístico Nacional (SPHAN), em 1937 (MEC / SPHAN / PRÓ-MEMÓRIA, 1980, p.89).

Inaugurou-se então uma nova fase para a história da arquitetura brasileira, marcada, desde o início do funcionamento do órgão, pela realização de pesquisas sistemáticas sobre a arquitetura brasileira, divulgadas através da Revista do Patrimônio Histórico e Artístico Nacional.

É justo, entretanto, que se reconheça também a importância das iniciativas aqui relacionadas, todas vinculadas ao movimento neocolonial, que constituíram etapa preparatória essencial para os desdobramentos da década de 1930. Papel, aliás, reconhecido por Mário de Andrade que, em seu balanço do neocolonial suscitado pela campanha "Contra o vandalismo e o Extermínio", liderada por Paulo Duarte em 1938, afirmou:

\begin{abstract}
Alguns anos atrás, ninguém ignora a campanha tão convincente que se fez em prol de uma arquitetura brasileira. Disso resultou o bem menos convincente "neo-colonial". Mas o espantoso é que ninguém cuidasse então, organizadamente, de preservar o colonial verdadeiro...

(...) Parece que nessa corrente, em que, aliás, há duas ou três exceções respeitáveis, ao menos uma coisa valiosa se fez. A documentação ajuntada. Quando uma arquitetura histórica, um desenho rupestre de primitivos, uma casa de taipa e outros elementos frágeis não podem ser guardados através do tempo, a tradição se preserva pela iconografia. (...) Se aludi ao fato, é que me parece de necessidade imediata reunir-se a documentação ajuntada por engenheiros e artistas diligentes, durante a campanha do neo-colonial, defendendo esses documentos da dispersão. E publicá-los de maneira raciona. (Carta a Paulo Duarte em setembro de 1937. In: DUARTE, 1985, p.150-1) ${ }^{39}$
\end{abstract}

Para concluir as presentes considerações, recorreremos mais uma vez a palavras de Rodrigo Melo Franco de Andrade, proferidas poucos anos após a criação do SPHAN, destacando a necessidade de conhecimento da arquitetura brasileira como uma das principais armas para a preservação de nosso patrimônio: 
... muito mais eficaz (...) será que os urbanistas, engenheiros e arquitetos, com qualquer parcela de responsabilidade, por mínima que seja, no estudo e no desenvolvimento dos vários projetos de remodelação das cidades, conheçam de perto os monumentos valiosos que aí se encontrem, a história de cada um deles e as qualidades artísticas que os caracterizem.

Só pelo conhecimento direto e não apenas ligeiro dessas obras do passado nacional, criadas com tamanho esforço e, às vezes, em condições tão pouco favoráveis, é que se aprende a considerá-las no seu verdadeiro sentido. Só do convívio com os monumentos e com a sua história poderá nascer a estima sincera que eles devem inspirar. Esse sentimento será como o de apego às pessoas e às coisas familiares. (Palestra em 27/09/1939, In: ANDRADE, 1987, p.54, grifos nossos).

\section{Notas}

${ }^{1}$ Trabalho realizado com recursos de Auxílio à Pesquisa da FAPESP - Fundação de Amparo à Pesquisa do Estado de São Paulo.

${ }^{2}$ Sobre o neocolonial, ver LEMOS (1985), AMARAL (1994), BOGHOSIAN (2002), KESSEL (2002) e PINHEIRO $(2005,2004,2003$ e 1997).

${ }^{3}$ Sobre a Missão Francesa, ver BARATA, 1959 e 1983; MORALES DE LOS RIOS FILHO, 1941; PUC-RJ, 1979; e RAMALHO, 1989.

${ }^{4}$ A pintura histórica constituía o mais elevado gênero de pintura do período, voltado exclusivamente para o registro de fatos e personagens históricos excepcionais, como fica claro nas considerações de Lebreton sobre as diferenças entre a pintura histórica e a pintura de gênero (BARATA, 1959, p.287).

${ }^{5}$ Trata-se das pranchas 42 e 43 e respectivos comentários. A prancha 41 apresenta o projeto de Grandjean de Montigny para a Academia de Belas Artes do Rio de Janeiro.

${ }^{6}$ Devo ao Prof. Júlio Katinsky a indicação deste texto.

${ }^{7}$ Ver a respeito KESSEL, 2002, p.48-53.

${ }^{8}$ Este aspecto parece ser corroborado pelo inexplicável ostracismo a que ficaram relegadas as interessantíssimas cartas que o engenheiro francês Louis Léger Vauthier escreveu durante sua estadia no Recife, entre 1840 e 1846, a seu amigo César Daly, editor da Revue Génerale de l'Architecture et des Travaux Publics - e que versavam inteiramente sobre a arquitetura e aspectos construtivos brasileiros, em análises incomparavelmente mais profundas que as de Debret. Este material permaneceu praticamente ignorado até a década de 1940, quando foi publicado na Revista do IPHAN (v.7, 1943). Possivelmente, a grande distância de Vauthier em relação ao Rio de Janeiro - capital política e cultural brasileira - explica tal fato, ainda que a Revue Génerale fosse um periódico de grande circulação à época. Mas, pelo jeito, a arquitetura tradicional brasileira ainda não apresentava qualquer interesse para nenhum brasileiro, naquele momento.

${ }^{9}$ O Solar de Megaípe, sede de engenho pernambucano, foi demolido logo após a criação da Inspetoria Estadual de Monumentos Nacionais de Pernambuco, em 1928. José Mariano Filho escreveu outros artigos a respeito, como O Solar de Megaípe e O Pseudo Solar de Megaípe (1943, p.34-6 e p.43-4). 
${ }^{10}$ No início deste capítulo, Carvalho chegou a afirmar : "Embora não nos tenha legado a arquitetura colonial um só monumento digno de maior registro, transmitiu-nos a escultura alguns nomes de valia..." (grifos nossos).

${ }^{11}$ A demora na publicação da obra de Wasth Rodrigues, bem como a ausência de qualquer menção a Ricardo Severo em sua introdução, é indício de possíveis desentendimentos entre o engenheiro português e o pintor paulista. A encomenda de Severo a Wasth Rodrigues carece de comprovação documental, ainda que conste de várias referências bibliográficas (GONÇALVES,1977, p.12 e p.31; SANTOS, 1960, nota 34; SAIA, 1960, p.115). Ver a respeito PINHEIRO, 2005, p.93-4.

${ }^{12}$ Ver a respeito BOGHOSIAN, 2002.

${ }^{13}$ Sobre os projetos de lei anteriores, ver: ANDRADE, 1993; MEC / SPHAN / PRÓ-MEMÓRIA, 1980; PINHEIRO, 2005.

${ }^{14}$ Ver a respeito GONÇALVES, 1974, p.67; PINHEIRO, 2005, p.16.

${ }^{15}$ A série de artigos não é assinada, mas sua autoria é atribuída a Fernando de Azevedo por SANTOS, 1960, p.23. Foram entrevistados: Ricardo Severo (15/04/1926), José Wasth Rodrigues (16/04/1926), Alexandre de Albuquerque (17/04/1926) e José Mariano Filho (21/04/1926).

${ }^{16}$ São os seguintes os artigos publicados na Revista do Brasil: Arte religiosa no Brasil-Triunfo Eucarístico de 1733 (n.49, janeiro de 1920); Arte religiosa no Brasil- Arte Cristã (n.50, fevereiro de 1920); A arte religiosa no Rio (n.52, abril de 1920); Arte religiosa no Brasil- Em Minas Gerais (n.54, julho de 1920). As viagens renderam também os artigos Alphonsus, (18/07/1919) e Triumpho Eucharístico-Trecho duma conferência, publicados em $A$ Cigarra (Ano 6, n.123, 01/11/1919). Foram reproduzidos em KRONBAUER, 1993, que consultamos para o presente trabalho.

${ }^{17}$ Trata-se da questão relativa à precedência cronológica da Candelária sobre a Basílica da Estrela - que, para Severo, teria servido de modelo à igreja carioca (artigo $A$ arte religiosa no Rio, de abril de 1920; in KRONBAUER, Op. cit. p.72).

${ }^{18}$ Ver a respeito AMARAL, 1992, p.155. Przyrembel fora, ademais, recentemente elogiado por Mário nas crônicas de 1920.

${ }^{19}$ Engenheiro-arquiteto formado em 1905, tornou-se professor da escola em 1917, tendo assumido em 1919 as cadeiras de "História da Arquitetura, Estética, Estilos" do $2^{\circ}$. e do $3^{\circ}$. anos (FICHER, 1989, p.147).

${ }^{20}$ Não são mencionadas as datas de tais viagens, mas a relação dos "engenheirandos" que comprovadamente participaram de tais excursões - com suas respectivas datas de conclusão do curso - é a seguinte: Amador Cintra do Prado (1921), José Maria da Silva Neves (1922), Alberto de Sá Moreira (1924), Raul Bolliger (1925), Carlos Gomes Cardim Filho (1925), Marcial Fleury de Oliveira (1926) e Ferrucio Pinotti (1926) 
${ }^{21}$ Aspecto corroborado por Paulo Santos (1960, p.26).

${ }^{22}$ Alguns de seus alvos prediletos eram os arquitetos Memória e Cuchet, herdeiros do escritório do prestigiado arquiteto Heitor de Mello e autores do Palácio das Indústrias e do Palácio das Festas na Exposição de 1922, e do clube Botafogo Futebol e Regatas, de 1926. Outro alvo das críticas de José Mariano foi Victor Dubugras cuja "excessiva fantasia", entretanto, não pode ser exclusivamente imputada ao seu desconhecimento da arquitetura colonial: ele teve contato in loco com muitas obras daquele período, como o Sítio do Padre Inácio (PINHEIRO, 2005, p. 63). Também consta que teria realizado o levantamento de uma casa do século XVIII, em Niterói, com seus alunos (MOTTA, 1957, p. 53).

${ }^{23}$ Não faltaram interpretações a apontar, aí, indícios precoces de desengano de Lúcio Costa em relação ao neocolonial. Levando-se em conta a sua trajetória profissional posterior, porém - composta, até c. 1930, exclusivamente de projetos 'em estilo', com predominância do neocolonial hispânico - é impossível concordar com essa hipótese. A chave de leitura adequada para esta enigmática passagem parece ser sua concordância em relação à falta de rigor estilístico então imperante na arquitetura neocolonial carioca - aspecto constantemente apontado por Mariano Filho naqueles anos, como vimos.

24 A criação dessa inspetoria é citada por Fonseca (1997, p.102), mas não tem comprovação documental. Entretanto, Mello Viana esteve envolvido em outras iniciativas de cunho turístico, tais como o início da construção do Balneário de Araxá (PORTO, 2005, p.140).

${ }^{25}$ Nereu Sampaio é o único a mostrar-se sensibilizado a este respeito, lastimando o desaparecimento de alguns "exemplos magníficos" de "casa bem adaptada ao nosso clima e às necessidades da época", como um velho solar em Brás de Pina, cujo levantamento arquitetônico ele teve a oportunidade de realizar (COSTA, 1927, p.252-3). Ver a respeito PINHEIRO, 2005, p.137-8.

${ }^{26}$ Este é assunto ainda a ser aprofundado em pesquisas na imprensa do período. Uma dificuldade a ser superada é a falta de indicação da data de publicação da maioria dos artigos de jornais reproduzidos nas várias coletâneas que José Mariano Filho organizou, na década de 1940.

${ }^{27}$ Ver a respeito PINHEIRO, 2005, p. 69 e 132-3.

${ }^{28}$ Em 1921, o concurso foi vencido por Nereu Sampaio e Gabriel Fernandes. Em 1923, o 'Prêmio Heitor de Mello' coube a Ângelo Bruhns, ficando Lúcio Costa em $2^{\circ}$. lugar, e Nereu Sampaio em $3^{\circ}$. Ver a respeito KESSEL, 2002, pp. 93-5 e 110; e SANTOS, 1960, notas 38 e 39.

${ }^{29}$ Nesta ocasião, o $1^{\circ}$ lugar coube a um 'Portão' de Ângelo Bruhns, e os $2^{\circ}$. e $3^{\circ}$. lugares couberam a Lúcio Costa ('Portão' e 'Banco', respectivamente. A revista Ilustração Brasileira publicou a relação de vencedores em março de 1923 (PINHEIRO, 2005, p. 132).

${ }^{30}$ No início da década de 1920, José Mariano já publicava artigos sobre arte e arquitetura no jornal O Dia, "dirigido por Azevedo Amaral, que também contava, entre seus colaboradores, com Rodrigo Mello Franco de Andrade”. (KESSEL, 2002, p. 90). Em 1930, Mariano era Diretor-presidente da Empresa Gráfica O Cruzeiro. 
${ }^{31}$ O fato repercutiu amplamente na imprensa (PINHEIRO, 2005, p.71).

${ }^{32} \mathrm{Na}$ ENBA, o registro de mudança de diretoria utilizado nas atas das reuniões da Congregação era bastante peculiar. Não se fazia qualquer menção explícita ao fato; apenas registrava-se a abertura da sessão com a presença do diretor cujo mandato acabava de expirar, e, no final, constava a assinatura do novo diretor. Assim, a data da primeira reunião da Congregação da ENBA em cuja ata comparece a assinatura de José Mariano Filho é 21 de maio de 1926, em substituição a João Batista da Costa, recentemente falecido então (Idem, ibidem)

${ }^{33}$ Sua nomeação chegou a ser considerada ilegal por lhe faltar "o único mas insofismável requisito legal, de pertencer ao magistério", conforme manifestaram os professores Flexa Ribeiro, Gastão Bahiana e Paulo Pederneiras. (Idem, ibidem)

${ }^{34}$ Quanto às demais disciplinas propostas, Bahiana argumentou que a cadeira de Estatuária teria tão poucos alunos que poderia ser feito um acompanhamento individual, e que a cadeira de Física poderia ser incluída na cadeira de Construção (Idem, p.72)

${ }^{35}$ Não se pode deixar de pensar no paralelismo entre a iniciativa de Mariano Filho e a luta de Viollet-le-Duc para incluir uma disciplina sobre Arte Medieval na École des Beaux Arts de Paris.

${ }^{36}$ De acordo com o sistema vigente na ENBA, a reunião teve início ainda presidida por José Mariano Filho, mas a ata já não foi assinada por ele.

37 A despeito da acirrada reação que enfrentou, José Mariano tinha também seus partidários entre o corpo docente da escola, inclusive entre artistas ligados ao modernismo, como Hélio Selinger (COSTA, 1927, p.163). A respeito de Selinger, Ver AMARAL, 1972, p.240.

${ }^{38}$ São listados aí os componentes da administração mineira na ocasião, da qual fazia parte também Francisco Campos, como Secretário do Interior.

${ }^{39}$ Infelizmente, Mário não foi explícito quanto às "exceções respeitáveis" que mencionou.

\section{Referências Bibliográficas}

ALBUQUERQUE, Alexandre. Aleijadinho e Arte Colonial. Boletim do Instituto de Engenharia n.63, agosto de 1930, pp. 59-62.

AMARAL, A. (org.). Arquitectura neocolonial: América Latina, Caribe, Estados Unidos. São Paulo: Memorial / Fondo de Cultura Económica, 1994.

Artes Plásticas na Semana de 22. São Paulo: BOVESPA / BM\&F, 1992.

ANDRADE, Antônio Luís Dias de. Um Estado Completo que pode jamais ter existido. São Paulo, FAU-USP, Tese de Doutoramento, 1993. 
ANDRADE, Mário. O Aleijadinho e a sua Posição Nacional. In: Depoimentos 2 / Mário de Andrade. São Paulo, GFAU da USP, 1966, p. 14.

ANDRADE, Rodrigo Melo Franco de. Rodrigo e o SPHAN - coletânea de textos sobre o patrimônio cultural. Rio de Janeiro: MinC / Fundação Nacional Pró-Memória, 1987.

BANDEIRA, Manuel. Crônicas da Província do Brasil. Rio de Janeiro: Civilização Brasileira, 1937.

BARATA, Mário. Manuscrito Inédito de Lebreton - Sobre o estabelecimento de dupla escola de Artes no Rio de Janeiro, em 1816. In: Revista do Patrimônio Histórico e Artístico Nacional n. 14. Rio de Janeiro, Ministério da Educação e Cultura, 1959.

BOGHOSIAN, Marianna Ramos. A Arquitetura Neocolonial Paulista. Caderno de Projetos Levantados. Relatório Final da Pesquisa PIBIC-CNPq, 2002.

BOITO, Camillo. Os Restauradores. Tradução: Beatriz Mugayar Kühl e Paulo Mugayar Kühl. São Paulo: Ateliê, 2002.

COSTA, João Angyone. A inquietação das abelhas (o que pensam e o que dizem os nossos pintores, escultores, arquitetos e gravadores, sobre as artes plásticas no Brasil). Rio de Janeiro, Pimenta de Mello, 1927.

COSTA, Lúcio. O Aleijadinho e a arquitetura tradicional. In: Sobre Arquitetura. Porto Alegre, CEUA, 1962.

CUNHA, Euclides da. Os Reparos nos Fortes de Bertioga (1904). In: Obra Completa. Rio de Janeiro: José Aguilar, 1996.

DEBRET, Jean-Baptiste. Viagem Pitoresca e Histórica ao Brasil. São Paulo: Martins, 1965, v. 3.

DUARTE, Paulo. Mário de Andrade por Ele Mesmo. São Paulo: Hucitec, 1985.

O ESTADO DE SÃO PAULO. Arquitetura Colonial - I-IX. São Paulo, edições publicadas nos dias 13-17, 21, 29 e 30 de abril de 1926.

FICHER, Sylvia. Ensino e profissão: o curso de engenheiro-arquiteto da Escola Politécnica de São Paulo. Tese de Doutorado, FFLCH-USP, São Paulo, 1989.

FONSECA, Maria Cecília Londres. O Patrimônio em Processo - Trajetória Política Federal de Preservação no Brasil. Rio de Janeiro: UFRJ / Minc / Iphan, 1997.

GONÇALVES, Ana Maria do Carmo Rossi. A obra de Ricardo Severo. Trabalho de Graduação Interdisciplinar, FAU-USP, São Paulo, 1977.

ILUSTRAÇÃO BRASILEIRA. Periódico mensal, Rio de Janeiro Números publicados na década de 1920. 
KESSEL, Carlos. Entre o Pastiche e a Modernidade: arquitetura neocolonial no Brasil. Tese de Doutorado, Programa de Pós-Graduação em História Social da UFRJ, Rio de Janeiro, 2002.

KRONBAUER, Claudete (org.). A Arte Religiosa no Brasil. Crônicas publicadas na Revista do Brasil em 1920. São Paulo, Experimento / Giordano, 1993.

LEMOS, Carlos. Alvenaria Burguesa. São Paulo: Nobel, 1985.

MARIANO FILHO, José. À Margem do Problema Arquitetônico Nacional. Rio de Janeiro: (s.n.), 1943.

MEC/SPHAN/PRÓ-MEMÓRIA. Proteção e Revitalização do Patrimônio Cultural no Brasil: uma Trajetória. Brasília, 1980.

MORALES DE LOS RIOS FILHO, Adolfo. Grandjean de Montigny e a Evolução da Arte Brasileira. Rio de Janeiro: A Noite, 1941.

MOTTA, Flávio Lichtenfels. Contribuição ao Estudo do Art-Nouveau no Brasil. São Paulo: (s.n.), 1957.

PINHEIRO, Maria Lucia Bressan. Enigmas de Lúcio Costa. In: NOBRE, Ana Luísa [et al.]. Um modo de ser moderno: Lucio Costa e a crítica contemporânea. São Paulo: Cosac \& Naify, 2004, pp. 299-304.

Modernizada ou Moderna? A arquitetura em São Paulo, 1938-45. Tese de Doutorado, FAU-USP, 1997.

O Neocolonial e o Edifício da Faculdade de Direito de São Paulo. In: Actas do 30. ENCORE - Encontro sobre Conservação e Reabilitação de Edifícios. Lisboa, Laboratório Nacional de Engenharia Civil-LNEC, 2003, pp. 165-174.

O Neocolonial e suas relações com o Patrimônio e o Modernismo. Relatório Final da Pesquisa apresentado à FAPESP, São Paulo, 2004.

Neocolonial, Modernismo e Preservação do Patrimônio no Debate Cultural dos Anos 1920 no Brasil. Textos para realização de Concurso de Livre-Docência. FAU-USP, São Paulo, 2005.

PORTO, Daniele. O Barreiro de Araxá. Dissertação de Mestrado EESC-USP, São Carlos, 2005.

PUC-RJ. DEPARTAMENTO DE ARTES. Uma Cidade em Questão I: Grandjean de Montigny e o Rio de Janeiro. Rio de Janeiro, PUC / Funarte / Fundação Roberto Marinho, 1979.

RAMALHO, Maria Lucia Bressan Pinheiro. Da Beaux-Arts ao Bungalow - uma amostragem da arquitetura eclética no Rio de Janeiro e em São Paulo. Dissertação de Mestrado FAU-USP, São Paulo, 1989. 
RANZINI, Felisberto. Estilo Colonial Brasileiro - Composições Arquitetônicas de Motivos Originais. São Paulo: Amadeus de Barros Saraiva, 1927.

RODRIGUES, José Wasth. Documentário Arquitetônico. São Paulo: EDUSP, 1979.

SAIA, Luís. Arquitetura Paulista. In: GFAU, Depoimentos 1, São Paulo, 1960, pp. 113-24.

SANTOS, Paulo. Presença de Lúcio Costa na Arquitetura Contemporânea do Brasil. Rio de Janeiro: datilografado, 1960.

SEVERO, Ricardo. A Arte Tradicional no Brasil. In: Sociedade de Cultura Artística. Conferencias 1914-1915. São Paulo: Typographia Levi, 1916.

SILVA, Maria Angélica da. As formas e as palavras na obra de Lúcio Costa. Dissertação de Mestrado PUC-RJ, Rio de Janeiro, 1991.

XAVIER, Alberto (org.) Arquitetura Moderna Brasileira: Depoimento de uma Geração. São Paulo: Pini / ABEA / Fundação Vilanova Artigas, 1987.

* Profa. Dra. do Departamento de História da Arquitetura e Estética do Projeto da Faculdade de Arquitetura e Urbanismo da Universidade de São Paulo.

Trabalho realizado com recursos de Auxílio à Pesquisa da FAPESP - Fundação de Amparo à Pesquisa do Estado de São Paulo 